\title{
Students' Self-Assessment: Other Way To Assess Competences At Higher Education
}

\author{
Isabel-María Ferrándiz-Vindel, Ph.D., University of Castilla-La Mancha, Spain
}

\begin{abstract}
At the High Education European Frame (EEES), we propose the necessity to generate a change in assess procedures and not only at the designs or at the methodology proposals to favour the development of the specific and transversal competences of each degree.

The objective of this work is to show how the student receives his/her learning process based on basic competences and how it can help him/her in the acquisition of the professional competences.

It is, in that way, why we use the self-assessment as a clarifying process which facilitates the educational identity of the didactic intervention. It defines the student situation face to the learning and at the same time it shows the effectiveness the teachers' action. Self-assessment can maybe be the best way to evaluate attitudinal contents so it causes self-reflection in the student to try to discover and identify the values which assume and the attitudes that are generated.
\end{abstract}

Keywords: Self-Assessment; EEES; Attitude Face To The Work; Professional Management

\section{INTRODUCTION}

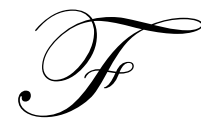

rom Bolonia's Declaration, in 1999, taken into account by 29 European countries, Spain has been walking together with the other 28 countries to the European Frame of High Education (EEES). What is for all of that? To obtain the implantation of a common frame of officially approved qualifications which permits a true mobility of European students; Why? Because they is a necessity to change completely formative processes for helping to construct and develop a Knowledge Europe in which the University is seen with the obligation to offer to its students an education and formation of quality based on new methodologies capable of creating competent citizens. (Michavila, F., 2008, p. 69).

All of those efforts which are been made to carry to the reality the European Frame of High Education (EEES), generates a certain worry about the way of adapt academic contents to the new exigencies. That is to say, what all of us know as "working through competences". But, what do we really understand by competence?

Spanish University wants to promote the acquisition of academic-professional competences. People requires, for their functions and social and work integration, to acquire certain abilities and skills such as instrumental, interpersonal and systematic. These competences are considered as a key university element that, apart from their academic speciality, it incorporates a variation of competences that given them more as person and as a future professional. (Villa, A. y Poblete, M, 2007).

For that reason, as professionals at the Human Sciences frame, the professional can make, with autonomy and responsability, intelectual acts which are not in their daily routines running to the objectives in complex situations. All these competences must permit that the professional moves not just his/her knowlegdes in a given situation but it also implies the mobility of a "knowing how to do" and a "knowing of being" specific to the educative job and those knowledges that must be learnt. (Rué, 2008)

The acquisition process of competences is continued because once they make a reflection of the daily practice, this measure will generate new occasions to improve the present competences. 
El proceso de adquisición de competencias es pues continuado ya que, en la medida en que se haga esta reflexión constante de la práctica, se irán generando nuevas ocasiones para mejorar las competencias 2002).

In that sense it is very important to get to the meta-cognition (Pedroza Flores, R., and Villalobos Monroy,

This reflexive process implies not only to have the specific knowledge about a matter (theoretical knowledges) and reflex about them and about the best way to transmit them (practical knowledges) but also in base to the environment analyse, the possible problems, to the receivers necessities, be able to change, create new representations, regulate the action implying practical, rational, instrumental and formal knowledges. (Zabalza, M.A., 2002).

We are dealing with a complex dimension that it can not only be result in the measure that a professional can access to the meta-competence which permits building ad rebuilding the own competences to the adaptation to each of the situations or demands.

The formative assessment and the self-assessment are the base for increasing at the professional frame and also to make possible the innovation and the change. It should drive us to reflex about our believes and our actions, to share those reflections with our colleagues, to listen their comments and to receive a retro-feeding about the work which has been done. (Cano, 2005, p. 184).

In this sense, self-assessment is a process which permits to the participant to know his/her potentialities and limitations and with them to take measures necessary to increment their knowledges and to look for help for overcoming the obstacles which cross through their learning process. This academic rise opens the door for uttering values' judges about their emotional and academic behaviour; it permits to analyse the reason of their successes and failures; it re-feeds their learning and it contributes to the one of their mates; with critic conciouness it evaluates their learning process accepting their success and failures. (Minerva Torres, 2005, 3).

\section{METHODOLOGY}

The objective of this study is the attitude face to work that student from the first course of Psicopedagogía show at Special Education's subject by using the self-assessment used no it, more in concrete those indicators which show obligation attitudes, satisfaction and participation in their job:

- $\quad$ Attitude face to work.

- $\quad$ Professional management.

A case design was used; when the teams were formed four months. The case design is a process of investigation in which the main aim is to understand a specific event which take place in a daily context and which also undertake a wide variety of sources of information.

The sample is formed by a Group of 66 students at the Psicopedagogia career, all of them have been registrated at the Special Education in the Castilla-La Mancha University, more in concrete at Cuenca's campus of which about the sample 50 were women ( $75.7 \%$ of the sample) and the 16 men (which are a $24.3 \%$ of the sample). About the total of the sample a $100 \%$ of them have already been degreed at any speciality of Magisterio and what it is more, we must say that the media of the reference group is 26 years old.

To obtain the information we used a self-assessment questionnaire made ad hoc, a Likert scale type with five options of response: absolutely without accordance with the value of 1 en the scale; without accordance (ED); with the same value to 2; parcially in accordance (PA), with a 3 of value; in accordance (DA), with the same value to 4 ; and totally in accordance (TA), with an equivalent value to 5 . 


\section{RESULTS}

After having passed the questionnaire, there were analysed the facts obtained which are going to be represented later on in this document. The starting point of this analysis is the item: 'Attitude face to work'.

After analysing the Facuss, we observe that all the measures are over four and 5 is the maximum value (totally in accordance) and the minimum 1 (totally in disaccordance). We may highlight the sum of ideas with a 4.39 and with a 0.653 of a typical deviation by contrasting the mode with the personal adequate item to the requirements of organizational image with a mean of 4.02 and a typical deviation of 0.794 .

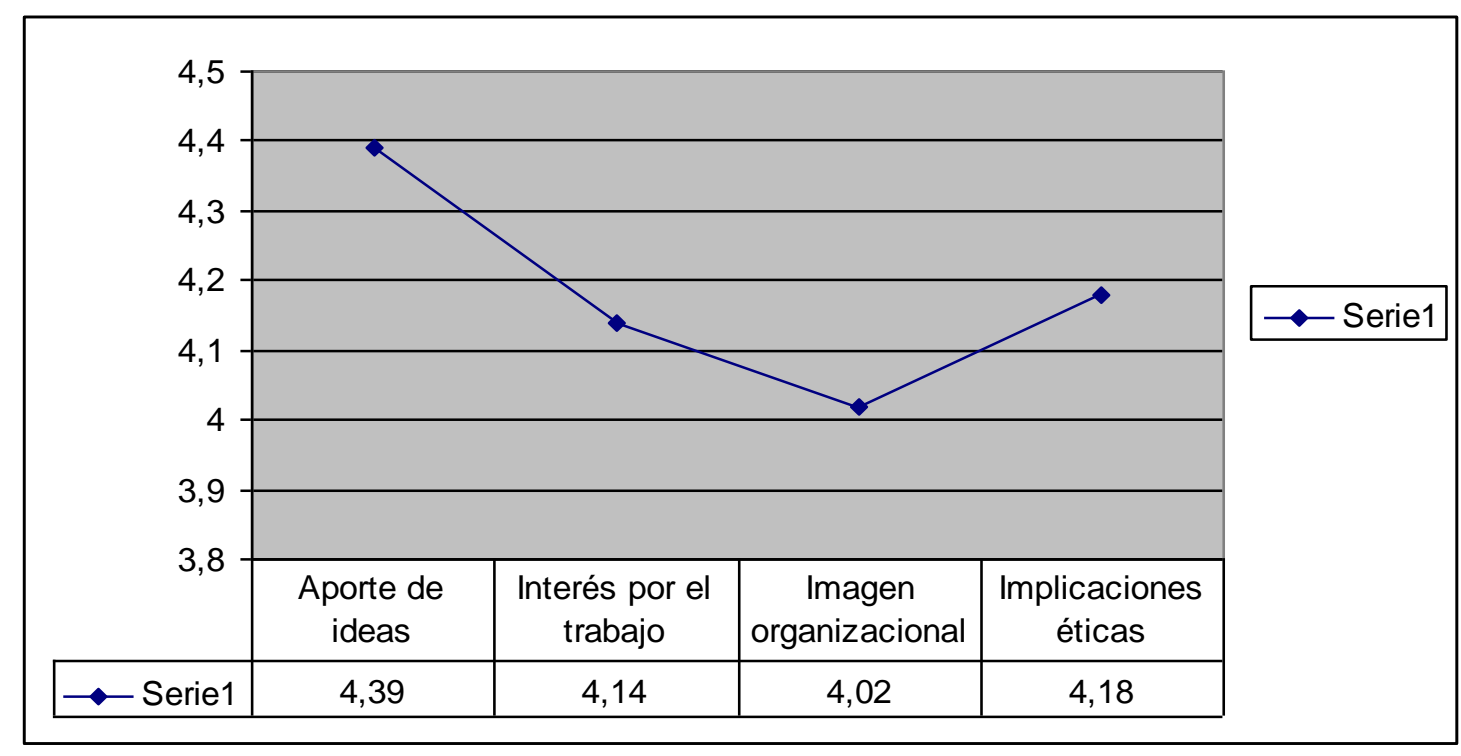

A) Referring to the competence 'Giving ideas, methods' proposal of working and resources research' (Mean $=4.39$ ).

As we can prove, students consider that they have a level more than acceptable ( $94 \%$ of the sample is 'totally in accordance' and 'in accordance'), that is to say, they are identified with their job, they participate on it and they consider their work important for their own consideration.

B) Referring to the competence: 'Disposition and interest for the job' (Mean $=4.14)$.

We contrast that student consider that they have acquired a considerable level ( $77.3 \%$ have a positive attitude), that is to say, the general attitude to their job as a whole of feelings and emotions which the students consider their job with.

C) En cuanto a la competencia 'Adecuate personal presentation to organizacional image requirements' $($ Mean $=4.02)$.

This competence is related to the grade in which the student identifies himself/herself with the organization and his/her goals and he/she desires to maintain on it as one of the members. By counting with the 'totally in accordance' answer, we also get a positive answer if we compare the $80.3 \%$ favourable to a $3 \%$ of a negative analysis.

D) Face to the competence: 'Aptitude to value ethical implications at organizations and work fulfilment' $($ Mean $=4.18)$.

We deduce that the students consider that once they have acquired ( $87.9 \%$ in the positive results) the competence that try to get certain objectives, also in those attitudes in which the ethic has an important component; what is more, it is just the one answer in which at this competence no negative solution has been found.

A date to highlight is, not with the item: 'Adequate personal presentation required to organizational image, in which we have obtained a positive value absolutely without accordance (1.5\%), the results present a positive analysis (since $77.3 \%$ to $94 \%$ depending on the item). 
We believe that those results are due to the initiative taken by the subject in which the paradigmatic change proposed since a creative Learning Model has promoted the learning, not for the class but for life. (Mariscal, 2008). In fact, students have comment that the activities realised with this Methodology have been agreable and they have felt identified with them. They have manifestated their interests and their goals they were trying to get before.

After analysis the obtained answers in the item: 'Professional Management', we can observe that the most part of the students of the sample have taken over the established expectations from the beginning referring to the subject.

At the interpretation of the date, we may consider the variability of the answers of some of the components of the class-group as it can be contrasted by observing the measures obtained in the questionnaires and their deviations.

Once the analysis has been done and the interpretation of the answers through statistics too (halves and their typical deviations) we can represent a student profile of the first course of Psicopedagogía in these competences and highlight the following:

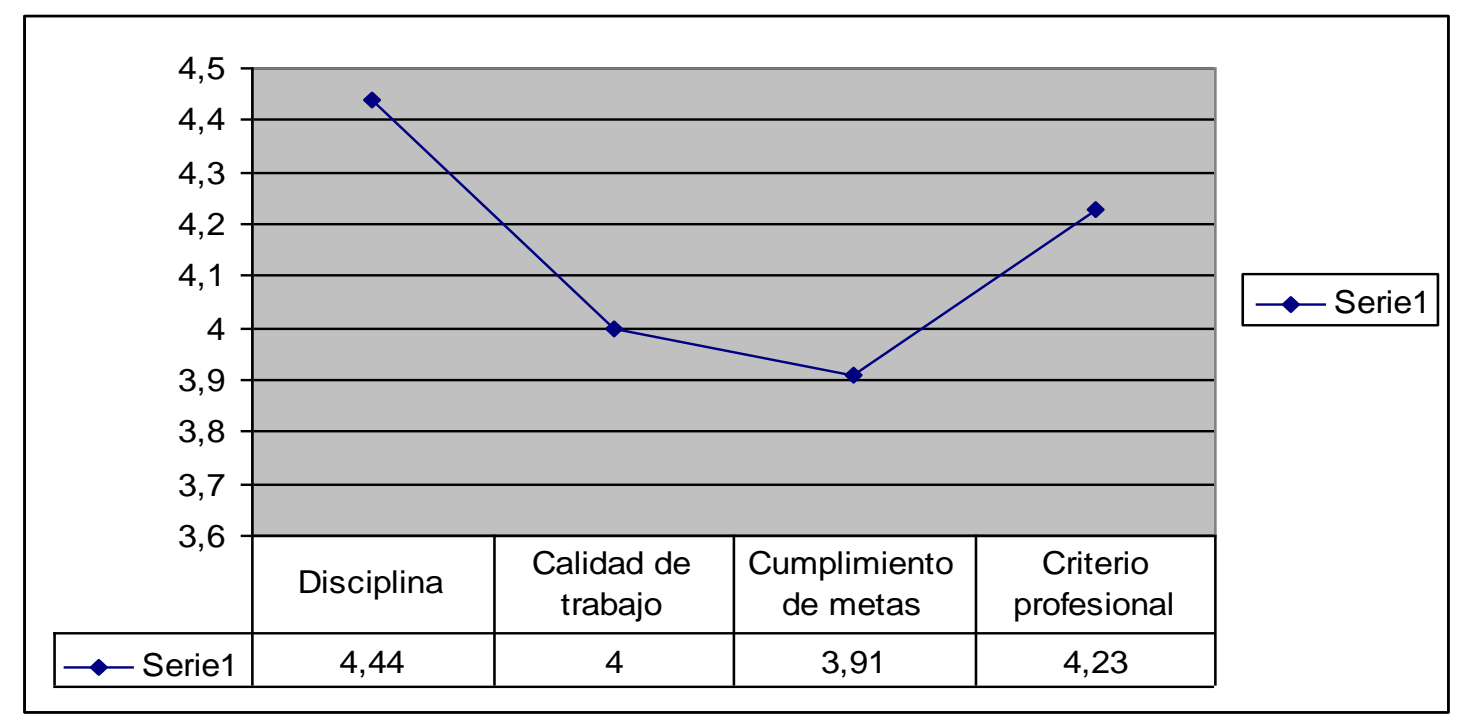

A) Referring to the competence "discipline" (Mean $=4.44 ; \sigma=0.747)$.

As we can contrast, students consider that they have a high level (a 54.5\% answered they were totally in accordance and a $37.9 \%$ are in accordance) of acquisition of the competence. Referring to formal demands of job, punctuality and presence which give us a capacity of influence and a view of future in advance contributing to that way to the best professional and personal development.

B) "Quality of working" (Mean $=4.00 ; \sigma=0.656)$.

We will check that the students consider that they have acquired a high level (a $19.7 \%$ is totally in accordance and a $62.1 \%$ in accordance) after analysing an exact grade, neatness and perfection in the job that the students consider that they have fulfil what it makes us to be implied to know how to be perfect at any activity trying to do it in a better way if possible.

C) The competence "Goals fulfillment" (Mean $=3.91 ; \sigma=0,696)$.

In that sense, we can observe that the students consider, respect to the previous competentes, that the acquisition of this one is more reduced although it takes over the expectations (a 18.2\% is totally in accordance and a $56.1 \%$ in accordance). It is the variable 'time and its organization' the one which has influenced in this less percentage.

D) Referring to the competence 'Professional criteria' (Mean $=4.23 ; \sigma=0.675$ ).

The balance of the own decisions and the capacity of searching practical and efficient solutions (professional criteria) by the part of the students, it continues with the same tonic that the rest of the factors which have been analysed. That is to say, it presents the results very important (with a $36 \%$ of response of totally in accordance and with a $50 \%$ in accordance). 


\section{CONCLUSIONS}

An improvement in the process of learning-teaching starts by an efficient self-assessment able to help to understand the mistakes done and to solve them in pos of a quality education (Calatayud, 2008).

This process of reflection must bring us to a self-critic attitude in the measure in which each person has the necessity to change some of the values assumed and any of the attitudes manifested, by other values which satisfied them more and that get on better with their way of understanding the life and the interpersonal relationships. The attitudinal contents' self-assessment facilitates to each person that they find their own scale of values as an essential part of their individual identity. This is going to permit them to know how to debate and say their own opinions, criteria and values in a wide context knowing to respect to those who can have criteria and different values.

Using the self-assessment to improve the quality face to the work bring us to the study of the competences employed in education in order to find the adequate answers face to the new mwthodologies and educative techniques (Cano, 2005).

After this study, we confirm the idea of Brown and Glasner (2007) that the self-assessment I the implication of the students identifying the standards and/or criteria to apply to their work and the realization of judgements about the extension that have been taken over with this criteria and standards. In the case of the students of the certificate of Psicopedagogía is linked to the participation of the work and the commitment with the organization because these students like the activities realised in the most participative subjects and they feel themselves identified with them by manifestating their interest to the objectives and the goals they fulfil.

\section{AUTHOR INFORMATION}

Isabel $\mathbf{M}^{\mathrm{a}}$ Ferrándiz Vindel, $\mathrm{PhD}$ and Degree in Education Sciences by Complutense University of Madrid (UCM), Spain. Professor in Pedagogy Department. Faculty of Education Sciences and Humanities of Cuenca. University of Castilla-La Mancha (Spain). E-mail: Isabel.Ferrandiz@uclm.es.

Research Interest: inclusive education of disabled people and or reduced mobility in all educational levels and the training of those professional who will teach them.

\section{REFERENCES}

1. Ansa P, M. and Acosta, A. (2008): La actitud hacia el trabajo del personal administrativo en el núcleo humanístico de la Universidad del Zulia. Revista de Ciencias Sociales, (XIV), pp. 121-130.

2. Brown, S. and Glasner, A. (2007): Evaluar en la Universidad. Problemas y nuevos enfoques. Madrid: NARCEA.

3. Calatayud, M. A. (2008): La autoevaluación como estrategia de aprendizaje para atender a la diversidad. http://www.educaweb.com/noticia/2008/01/28/autoevaluacion-como-estrategia-aprendiz

4. Cano, E. (2005): Cómo mejorar las competencias de los docentes: guía para la autoevaluación y el desarrollo de las competencias del profesorado. Barcelona: Grao.

5. Martín, A. and Fernández de Valderrama, L. (2008): Creatividad como competencia transversal de aprendizaje en estudios superiores. Valladolid: Universidad Europea Miguel de Cervantes

6. Michavila, F. (2008): LA UNIVERSIDAD, corazón de EUROPA. Madrid: TECNOS

7. Pedroza, R. and Villalobos, G. (2002): Mejoramiento de la calidad en la práctica profesional. Universidades, 23, 31-36. http://redalyc.uaemex.mx/redalyc/pdf/373/37302305.pdf

8. Rué, J. (2008): "Formar en competencias en la universidad: entre la relevancia y la banalidad". RED $U$ : Revista de Docencia Universitaria, 1. http://dialnet.unirioja.es/servlet/articulo?codigo $=2749773$

9. Villa, A. and Poblete, M. (2007): Aprendizaje basado en competencias. Una propuesta para la evaluación de las competencias genéricas. Bilbao: Mensajero

10. Zabalza, M. A. (2002): La enseñanza universitaria. El escenario y sus protagonistas. Madrid: Nancea. 
NOTES 